\title{
RNA/DNA ratio in milkfish (Chanos Chanos) larvae reared at different stocking densities
}

\author{
Rukisah Saleh1, Sitti Raehanah Muhamad Shaleh*2, Saleem Mustafa² and Sujjat Al-Azad² \\ ${ }^{1}$ Faculty of Fisheries and Marine Science, Borneo Tarakan University, Jalan Amal Lama No. 1, \\ Tarakan Kalimantan Utara, Indonesia \\ ${ }^{2}$ Borneo Marine Research Institute, Universiti Malaysia Sabah, Jalan UMS, 88400 Kota Kinabalu, Sabah, Malaysia
}

${ }^{*}$ Corresponding author: sittirae@ums.edu.my

\begin{abstract}
Stocking density can induce stress in fish in an aquaculture system if not handled properly, and the chronic stress may lead to mortality. Several studies have reported that the capability to deal with a range of stocking densities differs among fish species and maturity stage. Hence, fish larvae may have different resilience to stress from the adult fish. Milkfish larvae were reared in hatchery for 50 days using a recirculating culture system at four different stocking densities $(8,12,16$ and 20 larvae/liter). The growth performance was not significantly different $(P>0.05)$ except at stocking density of 20 larvae/liter. The highest survival rate (88.04\%) was recorded in the system with 8 larvae/liter while the lowest (55.44\%) in the culture tank where stocking rate was 20 larvae/liter. The stocking density also influenced the RNA / DNA ratio of the milkfish larvae. The RNA/DNA ratio showed a pattern that was identical with that of sigmoid growth where stocking rate of 8,12 , and 16 larvae/liter gained weight until 30 days of rearing. Highest RNA/DNA ratio was recorded at 16 larvae/liter (2.85 \pm 0.004$)$, while the lowest was at 20 larvae/liter (2.25 \pm 0.217$)$. Food availability might play a limiting factor that leads to the lower RNA/DNA ratio of larvae reared at a high density due to competition.
\end{abstract}

Keywords: Milkfish, Sustainable aquaculture, Hatchery rearing, RAS tank, Growth performance

\section{Introduction}

Milkfish culture in Indonesia is a widespread activity. A major factor in its growing popularity is that it thrives on ecosystem resources where benthic algae provide food for the milkfish. However, the ever-increasing demand for fish has generated interest in high-stocking density culture. This would require more operational inputs. Intensive and semi intensive systems are always associated with high stocking density (Kholifah et al., 2012) and requirement for supplementary feeds. A high-density carries the risk of stress and this can result in reduced growth and heavy mortality. Aquaculture industry should find a balance between the level of stocking and fish well-being for efficient and sustainable production. Several studies have reported that the capability to deal with a range of stocking density differs among fish species and maturity stage, and this factor should be considered in a culture system (Baldwin, 2010). This study was motivated by the need to determine the suitable stocking rate for rearing of milkfish larvae in the hatchery. RNA/DNA ratio has been used as the condition indicator to assess the effect of environmental factors and nutritional on growth and robustness of aquaculture animals (Mustafa et al., 1991; Gwak and Tanaka, 2001; Melissa and Mustafa, 2004). Assessment of growth and nutritional condition at different stocking levels could provide information of considerable significance in successful culture of milkfish. Changes in growth can be caused not only by lack of enough food, but also by sub-optimal environmental conditions or other factor like stocking density. The utility of this ratio is based on the fact that cellular DNA is relatively constant while changes in RNA content are aligned with protein biosynthesis. Therefore, the ratio of RNA and DNA can serve as an index of protein biosynthesis at a given time (Raae et al., 1988). Individuals in favorable condition are generally characterized by higher RNA/DNA ratio. In addition, RNA/DNA ratios also correlates possitively to changes in feeding conditions (Satterwhite, 2007). Therefore, RNA/DNA ratio can be used as an index of growth potential for fish in captivity (Buckley et al., 1999).

\section{Materials and Methods}

RNA/DNA ratios in milkfish larvae cultured at different stocking rates were analyzed. Twenty- day old milkfish larvae were obtained from local farmers in Tarakan, Indonesia. The experimental trials were carried out in fiberglass tanks, each of $80 \mathrm{~L}$ capacity, and connected to a system of water recirculation. Coral rubble and Aquamat ${ }^{\mathrm{TM}}$ were used as substrates or media for the filtration system. Experiment was conducted in triplicate sets with different stocking densities: 8, 12, 16 and 20 larvae/liter. Feed were given twice daily at 08:00 and 17:00. The feed was in the form of Bintang SB 001 containing 11\% moisture, 3\% fiber, $44 \%$ protein and $12 \%$ fat. To maintain water quality, uneaten feed and feces were siphoned out daily. Water temperature, DO and $\mathrm{pH}$ of each tank were also measured daily prior to feeding. 


\section{Sampling procedure and determination of nucleic acids}

Twenty larvae of milkfish were sampled randomly from each tank before the morning feeding every ten days. The larvae were washed with water and placed in an airtight container for storage at $-80{ }^{\circ} \mathrm{C}$. At the time of biochemical assays the fish were defrosted and samples taken out from the skeletal muscle were homogenized in ice-cold distilled water using a motorized homogenizer (Glas-Col, 230 V, USA) for 2 minutes. These tissues were centrifuged at $3000 \mathrm{rpm}$ for 15 minutes at $4^{\circ} \mathrm{C}$. The supernatant was then stored at $-20^{\circ} \mathrm{C}$ before further analysis. Colorimetric determination of RNA and DNA concentrations followed the procedures described by Mustafa (1997). One gram of sample was homogenized for 3 minutes. The homogenate was then treated with $5 \mathrm{ml}$ of cold distilled water and $5 \mathrm{ml}$ of cold $10 \%$ trichloroacetic acid (TCA) and centrifuged at $3000 \mathrm{rpm}$ for 15 minutes at a temperature of $15^{\circ} \mathrm{C}$. The supernatant was discarded and the residue was treated with $5 \mathrm{ml}$ of $10 \%$ cold TCA and centrifuged again at the same speed, temperature and duration. Later, the tissue residue was suspended in $5 \mathrm{ml}$ of $95 \%$ ethanol and centrifugation was carried out similarly. The supernatant was drained out to remove lipoidal substances. This was followed by the treatment of tissue residue with solvent ether, and then drying it in thermostat at $80^{\circ} \mathrm{C}$. The analysis of RNA and DNA concentration was done separately using $0.05 \mathrm{~g}$ of dry tissue for each assay and resuspending it in $5 \mathrm{ml}$ of $10 \%$ cold TCA before refrigeration for 12 hours.

\section{RNA analysis}

One ml of $1 \mathrm{~N} \mathrm{KOH}$ was added to each sample. The contents were incubated at $40^{\circ} \mathrm{C}$ for 20 hours, after which $0.25 \mathrm{ml}$ of $6 \mathrm{~N} \mathrm{HCl}$ was added and mixed thoroughly, followed by addition of $1 \mathrm{ml}$ of $5 \%$ TCA. Samples were mixed and centrifuged at $3000 \mathrm{rpm}$ at room temperature for 10 minutes. Aliquot measuring $0.05 \mathrm{ml}$ was pipetted into test tube and mixed with $0.95 \mathrm{ml}$ double distilled water. A freshly prepared orcinol reagent measuring $1 \mathrm{ml}$ was added to the contents and mixed thoroughly. The mixture was allowed to stand at $90^{\circ} \mathrm{C}$ for 60 minutes. Subsequently, the mixture was cooled down to room temperature. Optical density was determined using UV spectrophotometer at $660 \mathrm{~nm}$. RNA calibration curve was prepared using Yeast Type III RNA (Sigma) in the concentration range of 100-2000 $\mu \mathrm{g}$.

\section{DNA analysis}

DNA analysis involved adding $2.5 \mathrm{ml}$ of $5 \%$ TCA into each test tube containing the sample and heating the mixture in boiling water bath for 30 minutes. The evaporated volume was replaced using 5\% TCA. Samples were then centrifuged at $3000 \mathrm{rpm}$ at room temperature for 10 minutes. Supernatant measuring $0.25 \mathrm{ml}$ was mixed with $2.5 \mu \mathrm{l}$ of freshly prepared $5 \%$ cystein hydrochloride and $2.5 \mathrm{ml}$ of $70 \%$ sulfuric acid. The contents were mixed vigorously and incubated at $40{ }^{\circ} \mathrm{C}$ for 15 minutes with occasional shaking. Optical density of the solution was read by UV spectrophotometer at $490 \mathrm{~nm}$ after zeroing the optical density with a blank solution. DNA calibration curve was prepared using highly polymerized calf-thymus DNA (Sigma) in the range of 50 to $500 \mu \mathrm{g}$ concentration attained by serial dilution.

\section{Data processing}

The quantitative data on RNA and DNA were expressed as mean \pm standard error. Statistical analysis was conducted using statistical program SPSS version 16. One-way ANOVA was used to examine the differences among the samples. Statistical significance of the differences was expressed as $P<0.05$.

\section{Results}

It is evident from the data presented in Table 1 that there were no significant differences $(P>0.05)$ in growth and survival rate of milkfish larvae stocked at the densities of 8 , 12 and 16 individuals/ liter. However, at 20 larvae/liter, the growth and survival rate were adversely affected $(\mathrm{P}<0.05)$.

Table 1. Growth and survival rate of larvae milkfish at different stocking densities.

\begin{tabular}{|c|c|c|c|c|c|}
\hline \multicolumn{6}{|c|}{ Growth performance } \\
\hline $\begin{array}{l}\text { Stocking } \\
\text { rate } \\
(\text { tail/L) }\end{array}$ & $\begin{array}{l}\text { Initial } \\
\text { Weight } \\
\text { (mg) }\end{array}$ & $\begin{array}{l}\text { Final } \\
\text { Weight } \\
\text { (mg) }\end{array}$ & $\begin{array}{l}\text { Weight } \\
\text { gain } \\
\text { (mg) }\end{array}$ & $\begin{array}{l}\text { SGR } \\
(\% / d)\end{array}$ & $\begin{array}{l}\text { SR } \\
(\%)\end{array}$ \\
\hline 8 & 0.69 & $\begin{array}{l}52.70 \pm \\
0.43^{a}\end{array}$ & $\begin{array}{l}52.01 \pm \\
0.11^{\mathrm{a}}\end{array}$ & $\begin{array}{l}9.73 \pm 0 . \\
30^{a}\end{array}$ & $\begin{array}{l}88.04 \pm \\
17.50^{\mathrm{a}}\end{array}$ \\
\hline 12 & 0.69 & $\begin{array}{l}52.90 \pm \\
0.35^{\mathrm{a}}\end{array}$ & $\begin{array}{l}52.21 \pm \\
0.29 a\end{array}$ & $\begin{array}{l}9.80 \pm 0 . \\
79 a\end{array}$ & $\begin{array}{l}87.27 \pm \\
20.07 \mathrm{a}\end{array}$ \\
\hline 16 & 0.70 & $\begin{array}{l}53.00 \pm \\
0.49 \mathrm{a}\end{array}$ & $\begin{array}{l}52.31 \pm \\
0.61^{\mathrm{a}}\end{array}$ & $\begin{array}{l}9.80 \pm 0 . \\
16^{\mathrm{a}}\end{array}$ & $\begin{array}{l}87.72 \pm \\
15.51^{\mathrm{a}}\end{array}$ \\
\hline 20 & 0.70 & $\begin{array}{l}21.30 \pm \\
0.24^{b}\end{array}$ & $\begin{array}{l}20.61 \pm \\
0.27 \mathrm{~b}\end{array}$ & $\begin{array}{l}9.34 \pm 0 . \\
23^{\mathrm{b}}\end{array}$ & $\begin{array}{l}55.44^{ \pm} \\
11.06^{b}\end{array}$ \\
\hline
\end{tabular}

Note: Mean with different superscripts indicates significant difference $(\mathrm{P}<0.05)$.

$\mathrm{SGR}=$ specific growth rate $(\% / \mathrm{d}), \mathrm{SR}=$ survival rate $(\%), \mathrm{mg}=$ milligram.

RNA concentration showed a gradual increase from the beginning until $42 \mathrm{dAH}$ and after it gradually declined (Figure 1). The highest RNA concentration (259.10 \pm 0.30 $\mu \mathrm{g} / 100 \mathrm{mg}$ ) occurred at $42 \mathrm{dAH}$ (Table 2). In larvae stocked at 8,12 and 16 specimens/liter, RNA concentration maintained almost similar profile. RNA concentration increased from 22 to $42 \mathrm{dAH}$, and then continued to decrease until $52 \mathrm{~d}$ AH before increasing again at $62-72 \mathrm{dAH}$. At the density of 20 larvae/liter, RNA concentration showed a different pattern. At $32 \mathrm{~d}$ AH RNA concentration decreased from beginning to $32 \mathrm{dAH}$ and then slowly increased from 32 $\mathrm{dAH}$ until $72 \mathrm{dAH}$.

RNA concentrations in larvae stocked at different densities are presented in Figure 1. Evidently, RNA concentration of larvae at $22 \mathrm{dph}$ was recorded as not significantly different $(P>0.05)$ among the various stocking densities (Table 2). While the RNA concentration at $32 \mathrm{~d} \mathrm{AH}$ until $72 \mathrm{dAH}$ was not significantly different in larvae stocked at 8, 12, 16 per liter, it was significantly different at the density 20 larvae/liter. 
Table 2. Concentrations of RNA and DNA, and the RNA/DNA ratio in the milkfish larvae at different stocking densities.

\begin{tabular}{|c|c|c|c|c|}
\hline $\begin{array}{l}\text { Days } \\
\text { After } \\
\text { Hatching } \\
(\mathrm{dAH})\end{array}$ & $\begin{array}{l}\text { Stocking } \\
\text { density } \\
\text { larvae/L) }\end{array}$ & $\begin{array}{l}\text { RNA }(\mu / 100 \\
\text { mg) }\end{array}$ & $\begin{array}{l}\text { DNA }(\mu / 100 \\
\text { Mg) }\end{array}$ & $\begin{array}{l}\text { RNA / DNA } \\
\text { Ratio }\end{array}$ \\
\hline 22 & $\begin{array}{l}8 \\
12 \\
16 \\
20\end{array}$ & $\begin{array}{l}100.00 \pm 0.10^{\mathrm{a}} \\
100.97 \pm 0.06^{\mathrm{a}} \\
100.37 \pm 0.64^{\mathrm{a}} \\
103.33 \pm 5.77^{\mathrm{a}}\end{array}$ & $\begin{array}{l}71.00 \pm 1.00^{\mathrm{a}} \\
70.67 \pm 2.11^{\mathrm{a}} \\
69.67 \pm 1.53^{\mathrm{a}} \\
68.67 \pm 3.51^{\mathrm{a}}\end{array}$ & $\begin{array}{l}1.41 \pm 0.018^{\mathrm{a}} \\
1.43 \pm 0.041^{\mathrm{a}} \\
1.44 \pm 0.031^{\mathrm{a}} \\
1.50 \pm 0.106^{\mathrm{a}}\end{array}$ \\
\hline 32 & $\begin{array}{l}8 \\
12 \\
16 \\
20\end{array}$ & $\begin{array}{l}151.17 \pm 0.25^{\mathrm{a}} \\
152.10 \pm 0.80^{\mathrm{a}} \\
154.27 \pm 0.47^{\mathrm{a}} \\
61.20 \pm 0.10^{\mathrm{b}}\end{array}$ & $\begin{array}{l}81.20 \pm 0.96^{\mathrm{a}} \\
88.13 \pm 0.06^{\mathrm{a}} \\
88.23 \pm 1.22^{\mathrm{a}} \\
43.24 \pm 1.82^{\mathrm{b}}\end{array}$ & $\begin{array}{l}1.86 \pm 0.024^{\mathrm{a}} \\
1.73 \pm 0.008^{\mathrm{a}} \\
1.75 \pm 0.023^{\mathrm{a}} \\
1.42 \pm 0.056^{\mathrm{b}}\end{array}$ \\
\hline 42 & $\begin{array}{l}8 \\
12 \\
16 \\
20\end{array}$ & $\begin{array}{l}221.03 \pm 0.06^{\mathrm{a}} \\
231.30 \pm 0.20^{\mathrm{a}} \\
259.10 \pm 0.30^{\mathrm{a}} \\
81.17 \pm 16.40^{\mathrm{b}}\end{array}$ & $\begin{array}{l}120.03 \pm 0.15^{\mathrm{a}} \\
112.87 \pm 1.02^{\mathrm{a}} \\
120.30 \pm 0.10^{\mathrm{a}} \\
55.17 \pm 1.95^{\mathrm{b}}\end{array}$ & $\begin{array}{l}1.84 \pm 0.002^{\mathrm{b}} \\
2.05 \pm 0.017^{\mathrm{a}} \\
2.15 \pm 0.004^{\mathrm{a}} \\
1.47 \pm 0.249^{\mathrm{b}}\end{array}$ \\
\hline 52 & $\begin{array}{l}8 \\
12 \\
16 \\
20\end{array}$ & $\begin{array}{l}158.87 \pm 0.21^{\mathrm{a}} \\
161.17 \pm 9.55^{\mathrm{a}} \\
179.77 \pm 0.06^{\mathrm{a}} \\
87.13 \pm 11.24^{\mathrm{b}}\end{array}$ & $\begin{array}{l}59.50 \pm 0.53^{\mathrm{a}} \\
62.77 \pm 0.15^{\mathrm{a}} \\
63.10 \pm 0.10^{\mathrm{a}} \\
52.87 \pm 0.15^{\mathrm{b}}\end{array}$ & $\begin{array}{l}2.67 \pm 0.026^{\mathrm{a}} \\
2.57 \pm 0.154^{\mathrm{a}} \\
2.85 \pm 0.004^{\mathrm{a}} \\
1.65 \pm 0.212^{\mathrm{b}}\end{array}$ \\
\hline 62 & $\begin{array}{l}8 \\
12 \\
16 \\
20\end{array}$ & $\begin{array}{l}198.00 \pm 0.10^{\mathrm{a}} \\
198.20 \pm 1.65^{\mathrm{a}} \\
209.77 \pm 1.15^{\mathrm{a}} \\
101.17 \pm 0.35^{\mathrm{b}}\end{array}$ & $\begin{array}{l}73.97 \pm 0.42^{\mathrm{a}} \\
71.27 \pm 0.15^{\mathrm{a}} \\
75.20 \pm 0.20^{\mathrm{a}} \\
44.87 \pm 4.49^{\mathrm{b}}\end{array}$ & $\begin{array}{l}2.68 \pm 0.015^{\mathrm{a}} \\
2.78 \pm 0.029^{\mathrm{a}} \\
2.79 \pm 0.022^{\mathrm{a}} \\
2.25 \pm 0.217^{\mathrm{b}}\end{array}$ \\
\hline
\end{tabular}

Sub-indices over number denote significant differences (Duncan's multiple range test, $\mathrm{P}<0.05$ )

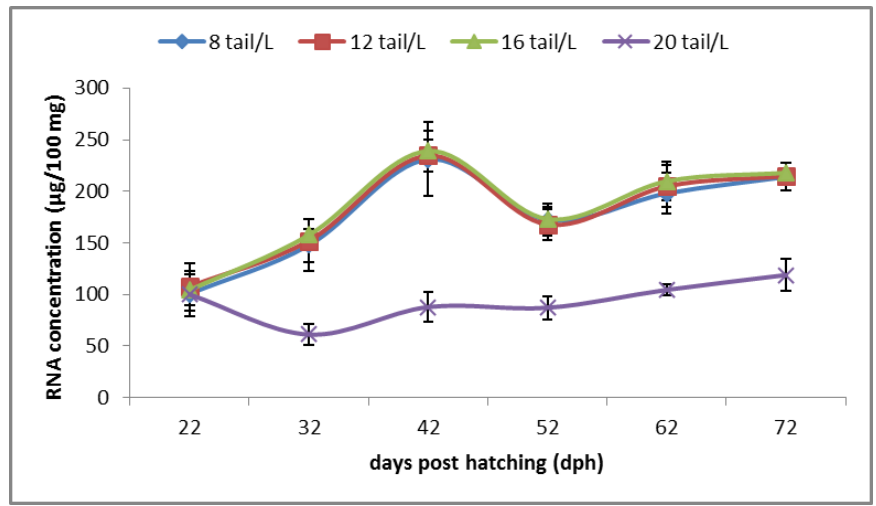

Figure 1. RNA concentration in milkfish juveniles stocked at different densities. Vertical lines indicate mean \pm SD

\section{DNA Concentration}

DNA concentration shows a fluctuation pattern similarly to RNA concentration. In larvae stocked at densities of 8, 12, 16 per liter the concentration increased from 32 to $42 \mathrm{dAH}$ and then decreased at $52 \mathrm{dAH}$ followed by an increase at $62 \mathrm{dAH}$ (Figure 2). The highest DNA concentration (120.30 \pm 0.10 $\mu \mathrm{g} / 100 \mathrm{mg}$ ) occurred at $42 \mathrm{dAH}$ (Table 2). At density of 20 larvae/liter, DNA concentration decreased from the beginning until $32 \mathrm{dAH}$ and increased until $42 \mathrm{dAH}$. From this stage it remained constant until the end of experiment (Figure 2). The highest DNA concentration $(55.17 \pm 1.95 \mu \mathrm{g} / 100 \mathrm{mg})$ was found at $42 \mathrm{dAH}$.
DNA concentrations in the larvae stocked at different densities showed no significant difference at $42 \mathrm{dAH}$ among those held at 8,12, and 16 individuals/liter (Table 2). The range of DNA concentration in larvae held in density of 8,12 , 16 and 20 per liter varied from $59.50 \pm 0.53$ to $120.03 \pm 0.15$ $\mu \mathrm{g} / 100 \mathrm{mg}, \quad 62.77 \pm 0.15$ to $112.87 \pm 1.02 \mu \mathrm{g} / 100 \mathrm{mg}$, $69.67 \pm 1.53$ to $120.30 \pm 0.10 \mu \mathrm{g} / 100 \mathrm{mg}, 43.24 \pm 1.82$ to $68.67 \pm 3.51 \mu \mathrm{g} / 100 \mathrm{mg}($ mean $\pm \mathrm{SD})$, respectively. DNA concentrations from 32 to $62 \mathrm{~d}$ AH were significantly different in density of 20 larvae/liter when compared to densities of 8, 12, and 16 larvae/liter $(P<0.05)$.

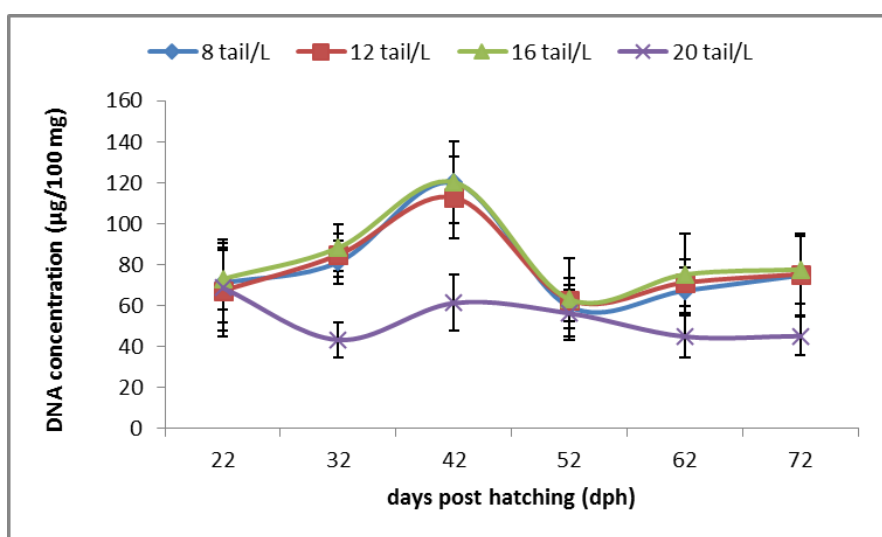

Figure 2. DNA concentrations in larvae stocked at different densities.

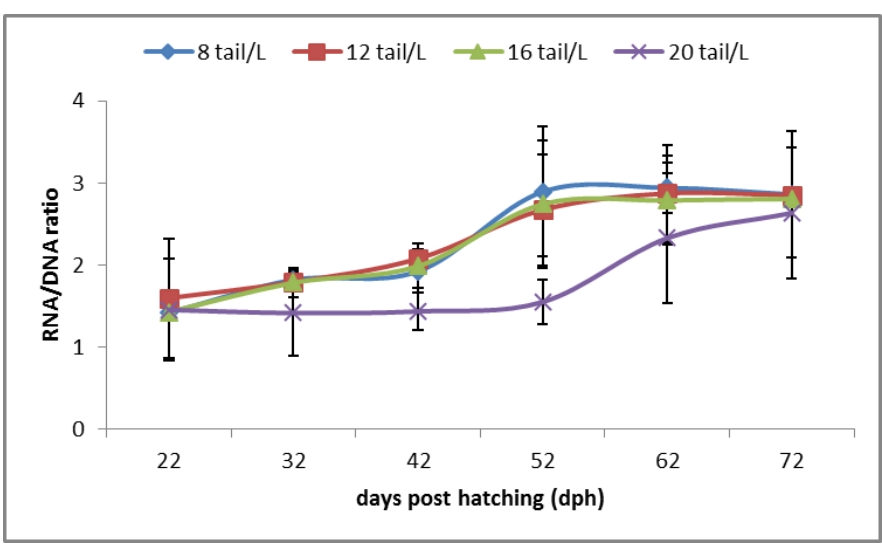

Figure 3. Comparison of RNA/DNA ratio in different density.

\section{RNA/DNA ratio}

RNA/DNA ratio in milkfish larvae stocked at the rate of 8, 12, 16 /liter showed increase from 22 until $52 \mathrm{dAH}$, followed by decline from 52 to $72 \mathrm{~d}$ AH (Figure 3). RNA/DNA ratio in the 20 larvae/liter group decreased slightly before increasing again from $32 \mathrm{dAH}$ until $72 \mathrm{dAH}$. The RNA/DNA ratio in larvae held at densities of $8,12,16$ and 20 per liter were recorded as $1.41 \pm 0.018$ to $2.68 \pm 0.015,1.43 \pm 0.041$ to $2.78 \pm 0.029,1.44 \pm 0.031$ to $2.85 \pm 0.004,1.50 \pm 0.106$ to $2.25 \pm 0.217$, respectively. Comparison of differences in RNA/DNA ratios among four densities shows lack of any significant difference $(P<0.05)$ when measured at $22 \mathrm{dAH}$ (Table 2). No significant difference was observed in the ratio in larvae reared at densities of 8,12, 16 per/liter at $32 \mathrm{dAH}$ until $72 \mathrm{dAH}$. However, a significant difference was noticed when the stocking density was 20 larvae/liter. 


\section{Discussion}

Differences in stocking density can influence the RNA/DNA ratio to various degrees in the milkfish larvae. In relation to environmental factors, Buckley et al. (1999) points out that lower temperature and higher food resources in winter are the main factor affecting RNA/DNA ratio. This was linked to an increase in RNA/DNA ratio in sardine larvae collected in spring. In the present study, RNA/DNA ratio, growth and survival better were observed to be higher when stocking rate was 16 larvae/liter or less. Food availability and environmental conditions could be the causative factors for decline in these parameters. It is likely that the decline in the ratio at $72 \mathrm{dAH}$ or earlier at was due to any of these factors. RNA/DNA ratio in this study shows a somewhat consistent pattern in the various treatment groups, except where the stocking density was 20 larvae/liter. At $22 \mathrm{dAH}$, the ratio increased from the beginning until $52 \mathrm{dAH}$. Based on the growth of larvae, it was significantly higher than others at that time. Density level does indeed play an important role. This result agrees with Huang and Chiu (1997) who studied the effects of stocking density in Nile tilapia fry and found that the fish size and production were significantly affected by the stocking density. Also, Canario et al. (1998) studied the effect of stocking density on the growth of Gilthead Seabream, Sparus aurata, and found that fish in the highest density group grew 25\% slower than fish in the lowest density group.

RNA/DNA ratios in this study appear to follow a pattern seen in growth in relation to stocking density. When stocking density was 20 larvae/liter, growth rate decreased, and mortality rate increased from the beginning until $61 \mathrm{~d} \mathrm{AH}$ because the larvae were under stress that caused appetite loss, and eventually mortality (Iwama, et al., 1997).

RNA/DNA ratio was highest when larval stocking density was $16 /$ liter until $52 \mathrm{~d}$ AH. This suggests a better nutritional condition compared to other density levels. Earlier studies have pointed linked increase in RNA/DNA to better larval condition (Buckley et al., 1999).

Clemmesen (1994) also concluded that fish larvae in good condition tend to have higher RNA/DNA ratio than those in poor condition (Clemmesen, 1994). In that sense, food availability might play as limiting factor for survival during early life phase (Setzler-Hamilton et al., 1987). It is no surprising that the food and space competition would reduce the nutrient intake and put stress on the captive fish should be reflected in decline in the RNA/DNA ratio in the larvae.

After 52 dAH, RNA/DNA ratio at 20 larvae/liter showed an increase and remained steady until the end of the experiment. When stocking density was 8, 12,16larvae/liter the ratio decreased until $72 \mathrm{dAH}$. The nutritional status of larvae at 20 individuals/liter can be rated as low based on RNA/DNA ratio. High energy demand for growth would require more protein synthesis. An increase of RNA at $42 \mathrm{~d}$ $\mathrm{AH}$, at 16 larvae/liter can, therefore, align with higher metabolism. Combined with the need to sustain its basic maintenance, the nutrient reserves in muscle tissue are utilized to supply energy to all tissues of the body (Gwak and Tanaka, 2001).

In this study, higher growth of the larvae might be related to physiological processes of protein biosynthesis. Houlihan et al. (1993) mentioned that changes in body mass are a function of relative protein synthesis and RNA concentration. Therefore, RNA concentration expressed as a ratio of RNA to DNA can be used as a measure of capacity or potential for protein synthesis and growth (Houlihan et al., 1993).

Based on the results, fish stocking density is an important factor affecting growth, besides food supply and its quality, and environmental conditions (Lovell, 1989). Also, the fish stocking density could affect the efficiency of food utilization due to shortage of nutrient intake and stress (Chang, 1988). Obviously, the stocking density should be considered as an important factor controlling larval condition and mortality. RNA/DNA ratio can be regarded as a useful tool in condition assessment in the hatchery and other culture systems.

\section{Acknowledgement}

This project was supported by UMS Seed Money FRG0040ST-1/2006: 24 that supported the project 'Mass Production of Moina and Copepod for Fish Larval Rearing'.

\section{References}

Baldwin, L. (2010). The effects of stocking density on fish welfare. The Plymouth Student Scientist 4(1), 372-383.

Buckley, L., Calderone, E. \& Ong, T.L. (1999). RNA-DNA Ratio and other Nucleic Acid-Based Indicators for Growth and Condition of Marine Fishes. Hydrobiologia 401, 265-277.

Canario, A.V.M., Condeça, J., Power, D.M. \& Ingleton, P.M. (1998). The effect of stocking density on growth in gilthead sea-bream, Sparus aurata (L.). Aquaculture Research 29, 177-181.

Chang, W.Y.B. (1988). Fish production: Data synthesis and model development. pp. 41-49. In: Pond Dynamics/Aquaculture Collaborative Research Support Program. 6th Annual Administrative Report, Oregon State University, Oregon, USA

Clemmesen, C. (1994). The effect of food availability, age or size on the RNA/DNA ratio of individually measured herring larvae: laboratory calibration. Marine Biology 118, 377-382.

Gwak, W.S. \& Tanaka, M. (2001). Developmental Change in RNA:DNA Ratios of Fed and Starved Laboratory-Reared Japanese Flounder Larvae and Juveniles, and its Application to Assessment of Nutritional Condition for Wild Fish. Journal of Fish Biology 59, 902-915.

Houlihan, D.F., Mathers, E.M, \& Foster, A.R. (1993). Biochemical correlates of growth rate in fish. In Fish Ecophysiology (eds. Rankin, J.C. \& Jensen, F.B.). London: Chapman Hall. Chapter 2.

Huang, W-B. \& Chiu, T.-S. (1997). Effects of stocking density on survival, growth, size variation, and production of Tilapia fry. Aquaculture Research $28,165-173$

Iwama, G., Pickering, A., Sumpter, J. \& Schreck, C. (1997). Fish Stress and Health in Aquaculture. Cambridge University Press, Cambridge. 
Volume: 03 (1) | July 2019, 13 - 17

Kholifah, U., Ninis, T. \& Is, Y. (2012). The effects of stocking density to survival rate and growth of shrimp (Penaeus monodon) and milkfish (Chanos chanos). Department of Fisheries, Faculty of Engineering and Marine Science, Hang Tuah University.

Lovell, T. (1989). Nutrition and Feeding of Fish. An AVI Book, Van Nostrand Reinhold, New York, p 260.

Mustafa, S. (1997). Influence of Maturation on the Concentration of RNA and DNA in the Flesh of the Catfish Clarias batracus. Trans. Amer. Fish. Soc. $106,449-451$.

Mustafa, S., Lagardere, J.P. \& Pastoureaud, A. (1991). Condition indices and RNA:DNA ratio in overwintering European sea bass, Dicentrarchus labrax, in salt marshes along the Atlantic coast of France. Aquaculture 96, $367-374$.

Melissa, J.J. \& Mustafa, S. (2004). RNA, DNA and protein profiles in nauplii of tiger prawn, Penaeus monodon, in relation to nutritional condition of female broodstock. Journal of Aquaculture in Tropics 19 (3), 155-164.

Raae, A.J., Opstad, I., Kvenseth, P. \& Walther, B.T. (1988). RNA, DNA and protein during early development in feeding and starved cod (Gadus morhua L) larvae. Aquaculture 73, 247-259

Satterwhite, M.C. (2007). RNA:DNA as an indicator of nutritional condition and growth in larval Naked gody Gobbiosoma Bosc. Thesis Faculity of the Louisiana State University and Agriculture and Mechanical College. In The Departement of Oceanography and Coastal Science.

Setzler-Hamilton, E.M.D.A., Millsaps, F.D. \& Whitlow, C.V. (1987). Analysis of nutritional condition and its use in predicting stripe bass recruitment: field studies. Am Fish Soc Symp 2,115-128. 